\title{
TITIK KRITIS PENYIAPAN SAMPEL UJI PROFISIENSI RESIDU PESTISIDA PADA MATRIKS KADAR AIR TINGGI: STUDI KASUS MATRIKS STROBERI
}

\author{
Critical Point Of Preparation Of Pesticide Residue Proficiency Testing Sample \\ On High Water Matrices : Case Study Strawberry Matrices
}

\author{
Rosaria Nainggolan \\ Balai Pengujian Mutu Barang, Direktorat Standardisasi dan Pengendalian Mutu, Kementerian Perdagangan \\ J. Raya Bogor KM 26, Cirasas, Jakarta Timur \\ E-mail: rosaria.nainggolan@gmail.com
}

\begin{abstract}
Abstrak
Telah dilakukan penyiapan sampel uji profisiensi residu pestisida pada berbagai matriks yang dipilih di Laboratorium Uji Residu Pestisida, Kementerian Perdagangan. Terdapat banyak tantangan dalam penyiapan sampel uji profisiensi ini. Sebelum dibagikan kepada peserta, salah satu hal yang dilakukan oleh laboratorium adalah memastikan homogenitas residu pestisida dalam keseluruhan matriks yang sudah disiapkan. Serangkaian kegiatan yang dilakukan di laboratorium mulai dari feasibility study, penyiapan sampel, penambahan sejumlah konsentrasi tertentu dari analit target, uji homogenisasi sampai uji stabilitas sampel uji profisiensi. Berdasarkan evaluasi dari laboratorium, terdapat tujuh titik kritis yang harus diperhatikan selama penyiapan sampel uji profisiensi. Kondisi alamiah matriks sampel mempengaruhi perbedaan perlakuan spiking contohnya pada matriks stroberi, dimana spiking dengan menggunakan pestisida formulasi komersial akan memberikan hasil lebih homogen dibandingkan dengan spiking dengan larutan standar. Evaluasi statistik berdasarkan ISO 13528:2015, di mana sampel dianggap stabil jika memenuhi persyaratan $\mathrm{Xr}-\mathrm{Yr} \leq 0.3 \sigma$, pestisida yang stabil hanya Acephate dan Methomyl, tetapi perhitungan stabilita dalam rentang waktu pengerjaan sampel menunjukkan bahwa konsentrasi residu pestisida tidak terdapat penurunan konsentrasi pestisida secara signifikan.
\end{abstract}

Kata Kunci: uji profisiensi, uji homogenitas, stabilitas, residu pestisida

\begin{abstract}
Pesticide residue proficiency test samples have been prepared on various selected matrix at the Pesticide Residue Test Laboratory, Ministry of Trade. There are challenges in preparing this proficiency test sample. Before distributed it to participants, the laboratory needs to ensure the homogeneity of pesticide residues in the entire matrix that has been prepared. A series of activities are carried out in the laboratory start from the feasibility study, sample preparation, add a certain concentration of target analyze, homogenization test to sample stability test, and proficiency test. Based on the laboratory evaluation, there are seven critical points that must be considered during the preparation of proficiency test samples. The natural conditions of the sample matrix affect the differences in spiking treatment, as in the strawberry matrix, where spiking using commercial formulated pesticides gave more homogeneous results than spiking with standard solutions. Statistical evaluation based on ISO 13528: 2015, where the sample is considered stable if meet the requirements of $\mathrm{Xr}-\mathrm{Yr} \leq 0.3 \sigma$, only stable pesticides are Acephate and Methomyl, consequently the calculation of stability in the time span of processing the sample show that the pesticide residue concentration did not significantly decrease the pesticide concentration.

Keywords:proficiency testing, homogeneity test, stability, pesticide residues
\end{abstract}

\section{PENDAHULUAN}

Sebagai laboratorium rujukan nasional untuk pengujian residu pestisida, berdasarkan Keputusan Menteri Perindustrian Republik Indonesia nomor 805 tahun 2019, salah satu kegiatan yang rutin dilakukan oleh Laboratorium Uji Residu Pestisida, Kementerian Perdagangan adalah mempersiapkan sampel uji profisiensi residu pestisida untuk berbagai laboratorium uji residu pestisida di Indonesia. Berdasarkan SNI ISO/IEC 17043:2010 tidak dijelaskan bagaimana penyiap sampel uji profisiensi harus menyiapkan bahan untuk sampel uji profisiensi, SNI ISO/IEC 17043:2010 hanya menjelaskan secara umum mengenai ketentuan-ketentuan yang harus dipenuhi berkaitan dengan pelaksanaan uji profisiensi.

Pemilihan matriks sampel uji profisiensi berdasarkan kesepakatan bersama dalam suatu forum Focus Group Discussion yang dilaksanakan oleh jejaring laboratorium pengujian residu pestisida yang ada di Indonesia. Pertimbangan tingkat kesulitan matriks sampel menjadi alasan pemilihan sampel, sehingga tahapan clean up ekstrak akhir memainkan peran penting dalam preparasi sampel. Tomat sebagai matriks yang 
pertama dipilih untuk matriks uji profisiensi, mengandung kadar air tinggi dan senyawa organik polar. Salah satu masalah utama dalam deteksi residu pestisida pada produk pertanian adalah efek matriks; senyawa coekstraktif seperti: pigmen, asam lemak, gula, antara lain, mengganggu deteksi pestisida yang relatif mudah dibersihkan, dilanjutkan dengan jeruk yang mengandung senyawa organik polar juga memiliki kandungan asam tinggi, kemudian selada yang mengandung senyawa organik polar dan kandungan pigmen tinggi, beras yang mewakili sampel padatan merupakan komoditi pangan terbesar yang dikonsumsi di Indonesia dan terakhir stroberi, mewakili matriks yang mengandung kadar asam tinggi, juga dipilih dengan pertimbangan ketersediaan Quality Control Material (QCM) Food Analysis Performance Assessment Scheme (food chemistry testing service; UK Department for Environment, Food and Rural Affairs)/ FAPAS rencananya akan digunakan untuk mendapatkan assigned value beberapa residu pestisida target.

Makalah ini bertujuan merekam tahapan yang dilakukan laboratorium penyiap sampel uji profisiensi, dalam hal ini residu pestisida, agar bisa bermanfaat bagi jejaring laboratorium pengujian residu pestisida dalam memberikan informasi tentang hal-hal terkait penyiapan sampel uji profisiensi residu pestisida. Tahapan penyiapan sampel ini adalah tahapan kritis yang menentukan suatu penarikan kesimpulan "homogen" ataupun "stabil" yang kemudian sampel layak untuk didistribusikan ke peserta skema uji profisiensi.

Tahapan penyiapan sampel uji profisiensi ini mengacu pada beberapa publikasi ilmiah terkait pembuatan sampel uji profisiensi residu pestisida. Sampel uji profisiensi yang telah disiapkan, dianalisis dengan metode pengujian rutin di laboratorium untuk analisis sampel dengan kandungan asam tinggi berdasarkan metode BS EN 15662:2008 standard yang dikenal dengan metode QuEChERS (Quick, Easy, Cheap, Effective, Rugged, and Safe). Adapun perhitungan homogenitas dan stabilitas sampel uji profisiensi dihitung dengan menggunakan ISO 13528:2015.

Semoga makalah mengenai titik kritis tahapan penyiapan sampel uji prosisiensi khususnya untuk residu pestisida ini dapat memberikan gambaran pada laboratorium terkait tentang bagaimana mempersiapkan sampel uji profisiensi maupun uji banding residu pestisida di laboratorium ujinya masingmasing. Hal-hal yang perlu menjadi perhatian laboratorium penyiap sampel dalam setiap tahapannya akan dibahas selanjutnya.

\section{TINJAUAN PUSTAKA}

\subsection{Uji Profisiensi}

Dalam SNI ISO/IEC 17043:2010, uji profisiensi didefinisikan sebagai serangkaian kegiatan pengujian untuk mengevaluasi kinerja peserta terhadap kriteria yang telah ditetapkan sebelumnya melalui uji banding antar laboratorium. Berbicara mengenai uji profisiensi, tentunya akan selalu berkaitan dengan SNI ISO/IEC 17025:2017, baik laboratorium sebagai peserta kegiatan uji profisiensi, maupun laboratorium sebagai penyiap sampel uji profisiensi. Dalam SNI ISO/IEC 17025:2017 uji profisiensi / unjuk kerja didefinisikan sebagai evaluasi terhadap unjuk kerja laboratorium atas hasil kalibrasi / uji berdasarkan kriteria yang telah ditetapkan yang dapat menggunakan hasil uji banding.

Uji Profisiensi berdasarkan ISO/IEC Guide 43:1997 bagian 1 didefinisikan sebagai suatu perangkat yang powerfull untuk membantu laboratorium dalam menunjukkan kompetensinya kepada lembaga akreditasi atau pihak ketiga. Dengan kata lain uji profisiensi merupakan suatu metoda untuk mengetahui kinerja laboratorium dengan cara uji banding antar laboratorium. Uji profisiensi memungkinkan laboratorium memonitor hasil ujinya dari waktu ke waktu. Tren hasil pengujian dalam suatu jangka waktu yang cukup lama dapat diketahui sehingga bila ada penyimpangan yang terjadi dapat segera dipikirkan tindakan perbaikannya.

Pada uji ini semua laboratorium peserta melaksanakan suatu pengujian terhadap contoh uji yang sama dan hasilnya dibandingkan terhadap hasil dari laboratorium lainnya, maupun terhadap nilai bahan acuan. Contoh uji yang telah homogen didistribusikan kepada laboratorium peserta kemudian seluruh laboratorium menganalisis contoh tersebut secara serentak dan hasilnya kemudian dikumpulkan untuk diolah secara statistika.

Kaitannya dengan persyaratan ISO 17025 dan Metrologi Kimia Berdasarkan persyaratan ISO/IEC 17025, suatu laboratorium harus memiliki prosedur quality control untuk memonitor validitas dari hasil uji dan kalibrasi yang dilakukan. Monitoring dapat meliputi keikutsertaan pada uji banding antar laboratorium atau program uji profisiensi dan juga dapat melalui penggunaan bahan acuan yang tersertifikasi atau dengan melakukan replikasi pengukuran menggunakan metoda analisa yang sama atau berbeda. Dengan demikian laboratorium dapat menyediakan bukti kompetensinya pada pelanggannya dan kepada lembaga akreditasi. 


\subsection{Uji Homogenitas dan Stabilitas}

Menurut Aidah (2008), arti uji homogenitas adalah sebagai pengujian keserbaasaman, maksudnya sampel yang diberikan kepada seluruh peserta memiliki jumlah dan komposisi yang sama. Ketidakhomogenan sampel dapat mengakibatkan nilai analisa yang bervariasi sehingga sulit dalam pengolahan data serta dapat mengakibatkan laboratorium mendapat nilai outlier dan hal ini bukan karena peralatan yang kurang baik atau personil yang tidak kompeten tapi karena sampel yang dianalisa tidak homogen.

Penyedia sampel uji profisiensi harus memastikan bahwa sampel uji profisiensi yang akan dibagikan ke peserta sudah homogen dan stabil untuk keperluan skema uji profisiensi. Penyelenggara uji profisiensi harus menilai homogenitas dan stabilitas menggunakan kriteria yang memastikan bahwa ketidakhomogenan dan ketidakstabilan sampel uji profisiensi tidak mempengaruhi evaluasi kinerja peserta. Menurut ISO 13528:2015(E) Penilaian homogenitas dan stabilitas harus menggunakan satu atau lebih dari pendekatan berikut:

a. studi eksperimental atau metode eksperimental alternatif yang menyediakan kepastian yang setara atau lebih besar dari homogenitas dan stabilitas;

b. pengalaman dengan perilaku sampel uji profisiensi yang sangat mirip di pelaksanaan skema uji profisiensi sebelumnya, diverifikasi seperlunya untuk pelaksanaan saat ini;

c. penilaian data peserta dalam pelaksanaan dari skema uji profisiensi saat ini untuk bukti konsistensi dengan pelaksanaan sebelumnya, untuk bukti perubahan dengan waktu pelaporan atau produksi sampel, atau perubahan tak terduga yang disebabkan oleh ketidakhomogenan atau ketidakstabilan.

\subsection{Residu Pestisida dalam Skema Uji Profisiensi \\ Residu pestisida yang digunakan untuk} analit target dalam suatu kegiatan uji profisiensi dapat diperoleh secara alami, artinya secara alami terkandung dalam matriks kandidat sampel uji profisiensi, maupun ditambahkan dengan cara spiking. Tetapi sangat sulit untuk mendapatkan residu pestisida dalam sejumlah besar matriks sampel secara homogen, dengan pertimbangan itu, maka residu pestisida target ditambahkan dengan cara spiking ke dalam matriks.
Ada beberapa regulasi batas cemaran residu pestisida yang dapat dijadikan acuan oleh penyelenggara uji profisiensi untuk melakukan spiking ataupun penyemprotan terhadap matriks target, diantaranya Peraturan Menteri Pertanian Republik Indonesia (53/PERMENTAN/KR.040/12/2018), SNI 7313:2008, European Commission: Information on pesticide EU MRLs ataupun peraturan mengenai batas cemaran residu pestisida di negara tujuan ekspor komoditi tertentu.

\section{METODE PENELITIAN}

\subsection{Feasibility Study Oleh Laboratorium Penyiap Sampel Uji Profisiensi}

Sebelum mempersiapkan sampel uji profisiensi Laboratorium Uji Residu Pestisida, Direktorat Standardisasi dan Pengendalian Mutu, Kementerian Perdagangan memulai dengan kegiatan feasibility study, untuk melihat stabilitas dan homogenitas selama rentang waktu tertentu. Sebagaimana yang dilakukan Grimalt (2015) dalam memproduksi bahan acuan residu pestisida pada matriks timun. Tahapan penyiapan sampel untuk feasibility study sama dengan tahapan penyiapan sampel uji profisiensi, hanya dalam jumlah yang lebih sedikit, yang mencukupi, sesuai dengan rentang waktu pengamatan kestabilan residu pestisida dalam matriks stroberi. Dengan pengamatan pada hari ke-0, ke-3, ke-7, ke-14, ke-21, ke-28. Pada perlakuan sampel di suhu $\pm 25-30^{\circ} \mathrm{C}$, suhu \pm $40^{\circ} \mathrm{C}$, suhu $\pm 4^{\circ} \mathrm{C}$ dan suhu $\leq 0{ }^{\circ} \mathrm{C}$

\subsection{Penyiapan Sampel Uji Profisiensi Pada Matriks Stroberi}

Tahapan preparasi sampel uji profisiensi stroberi adalah sebagai berikut:

a. Stroberi dibersihkan dari mahkotanya

b. Stroberi diblender sampai halus

c. Stroberi disaring dengan ayakan mesh no. 20 sampai didapatkan jumlah puree yang cukup

d. Puree stroberi ditambahkan dengan pengawet dan diaduk

e. Dilakukan analisis kandungan residu pestisida dalam puree stroberi

f. Dilakukan spiking residu pestisida dalam jumlah tertentu

g. Dilakukan pengadukan minimal 48 jam

h. Dilakukan pre sampling sebelum pengemasan

i. Dilakukan pengemasan sampel

j. Di evaluasi homogenisasi sampel 
Tabel 1 Data pestisida spiking puree stroberi

\begin{tabular}{|c|c|c|c|c|c|c|}
\hline Pestisida & No. Reg CAS & Formula & $\begin{array}{l}\text { Klasifikasi } \\
\text { fungsional }\end{array}$ & $\begin{array}{c}\text { MRL Stroberi } \\
\text { (EU Regulasi) } \\
(\mathrm{mg} / \mathrm{kg})\end{array}$ & $\begin{array}{c}\text { BMR } \\
\text { Stroberi } \\
\text { (SNI) } \\
(\mathrm{mg} / \mathbf{k g})\end{array}$ & $\begin{array}{c}\text { Kelarutan } \\
\text { (mg/L) }\end{array}$ \\
\hline Acephate & $30560-19-1$ & C4H10N1O3PS1 & Insecticide & $0.01^{*}$ & 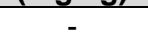 & 790000 \\
\hline Thiacloprid & $111988-49-9$ & $\mathrm{C} 10 \mathrm{H} 9 \mathrm{CIN} 4 \mathrm{~S}$ & Insecticide & 1 & - & 184 \\
\hline Carbofuran & $1563-66-2$ & $\mathrm{C} 12 \mathrm{H} 15 \mathrm{NO} 3$ & $\begin{array}{l}\text { Insecticide, } \\
\text { Acaricide, } \\
\text { Nematicide }\end{array}$ & $0.005^{*}$ & - & 315 \\
\hline Carbaryl & $63-25-2$ & $\mathrm{C} 12 \mathrm{H} 11 \mathrm{NO} 2$ & $\begin{array}{l}\text { Growth } \\
\text { regulator, } \\
\text { Insecticide, } \\
\text { Acaricide }\end{array}$ & $0.01^{*}$ & - & 9.1 \\
\hline Azoxystrobin & $131860-33-8$ & $\mathrm{C} 22 \mathrm{H} 17 \mathrm{~N} 3 \mathrm{O} 5$ & Fungicide & 10 & 10 & 6.7 \\
\hline Diazinon & $333-41-5$ & $\mathrm{C} 12 \mathrm{H} 21 \mathrm{~N} 2 \mathrm{O} 3 \mathrm{PS}$ & $\begin{array}{l}\text { Acaricide, } \\
\text { Insecticide, } \\
\text { Nematicide }\end{array}$ & $0.01^{*}$ & 0,1 & 60 \\
\hline $\begin{array}{l}\text { Chlorpyrifos } \\
\text { methyl }\end{array}$ & $5598-13-0$ & C7H7Cl3NO3PS & $\begin{array}{l}\text { Insecticide, } \\
\text { Acaricide }\end{array}$ & 0.06 & 0,06 & 2.74 \\
\hline Trifloxystrobin & $141517-21-7$ & $\mathrm{C} 2 \mathrm{OH} 19 \mathrm{~F} 3 \mathrm{~N} 2 \mathrm{O} 4$ & Fungicide & 1 & 1 & 0.61 \\
\hline Methomyl & $16752-77-5$ & $\mathrm{C} 5 \mathrm{H} 10 \mathrm{~N} 2 \mathrm{O} 2 \mathrm{~S}$ & $\begin{array}{l}\text { Acaricide, } \\
\text { Insecticide }\end{array}$ & $0.01^{*}$ & - & 55000 \\
\hline
\end{tabular}

*pestisida yang digunakan adalah beberapa pestisida formulasi yang dibeli pada toko penjual produk perawatan tanaman yang ada di Jakarta, ditambah pestisida standar analisis di laboratorium

\subsection{Preparasi sampel uji profisiensi}

Sampel uji profisiensi yang telah disiapkan, dianalisis dengan metode pengujian rutin di laboratorium untuk analisis sampel dengan kandungan asam tinggi berdasarkan metode BS EN 15662:2008 standard yang dikenal dengan metode QuEChERS (Quick, Easy, Cheap, Effective, Rugged, and Safe), untuk selanjutnya sampel di analisis dengan menggunakan instrumentasi LC-MS/MS atau GC-MS/MS. Sedangkan jaminan mutu internal laboratorium yang diterapkan mengacu pada dokumen SANTE/11813/2017 yang secara khusus mengatur tentang prosedur penjaminan mutu dan prosedur validasi untuk analisis residu pestisida pada sampel makanan dan pakan ternak.

\subsection{Uji Homogenitas dan Stabilitas Sampel Uji Profisiensi}

\subsubsection{Uji Homogenitas}

Dilakukan sesuai dengan prinsip dalam SNI ISO/IEC 17043:2010 dan ISO 13528:2015. Uji homogenitas ini dilakukan sebelum sampel dikirim ke laboratorium peserta uji profisiensi. Jika digambarkan, maka dapat dirangkum sebagai berikut, dimana menurut Palupi (2014), tahapan pelaksanaan uji homogenitas sampel uji profisiensi adalah:

a. Sampel yang dianggap sudah homogen dan sudah dikemas dalam kemasan dengan bobot tertentu, diambil secara acak oleh staf bagian mutu sebanyak 10 kemasan.

b. Setiap kemasan dibagi menjadi dua bagian dan diberi label A dan B untuk selanjutnya diuji dengan prosedur preparasi di laboratorium. Pengambilan sampel untuk uji homogenitas digambarkan sebagai berikut:
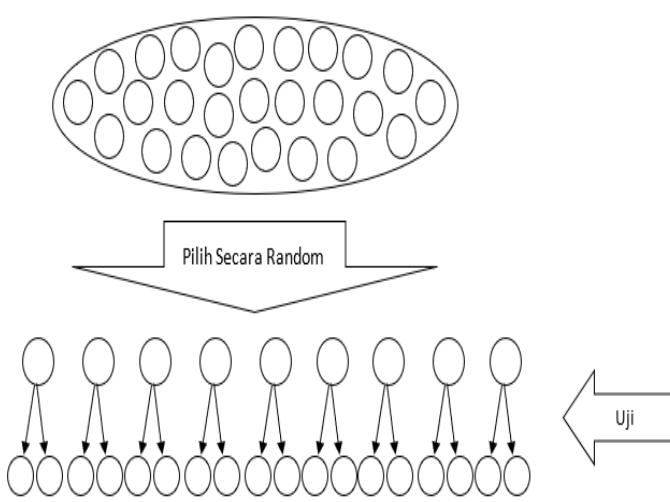

Gambar 1 Skematik Uji Homogenitas

c. Metode pengujian masing-masing sampel disesuaikan dengan metode pengujian di laboratorium.

d. Sampel dipreparasi kemudian dianalisis dengan instrumentasi LC-MS/MS atau GCMS/MS

e. Sampel dianggap homogen jika memenuhi persyaratan $\mathrm{Ss} \leq 0.3 \sigma$, dimana 
Ss $=$ standar deviasi between sample

$\sigma=$ standar deviasi untuk asesmen profisiensi (SDPA), yang ditetapkan dengan perhitungan $\mathrm{CV}_{\text {Horwitz. }}$

\subsubsection{Uji Stabilitas}

Dilakukan sesuai dengan prinsip dalam SNI ISO/IEC 17043:2010 dan ISO 13528:2015. Uji stabilitas ini dilakukan sebelum sampel dikirim ke laboratorium peserta uji profisiensi dan pada saat batas waktu peserta mengirimkan hasil uji ke penyelenggara uji profisiensi. Jika digambarkan, maka dapat dirangkum sebagai berikut, dimana Palupi (2014) menjelaskan bahwa tahapan pelaksanaan uji uji stabiliitas sampel uji profisiensi adalah:

a. Metode pengujian sampel disesuaikan dengan metode pengujian di laboratorium dan sama dengan metode uji yang digunakan pada saat melaksanakan uji homogenitas

b. Staf bagian mutu memilih kemasan contoh secara random sejumlah 3 kemasan

c. Dari 3 kemasan yang dipilih, masing-masing dibagi menjadi 2 untuk dianalisis duplo. Pengambilan sampel untuk uji stabilitas digambarkan sebagai berikut:
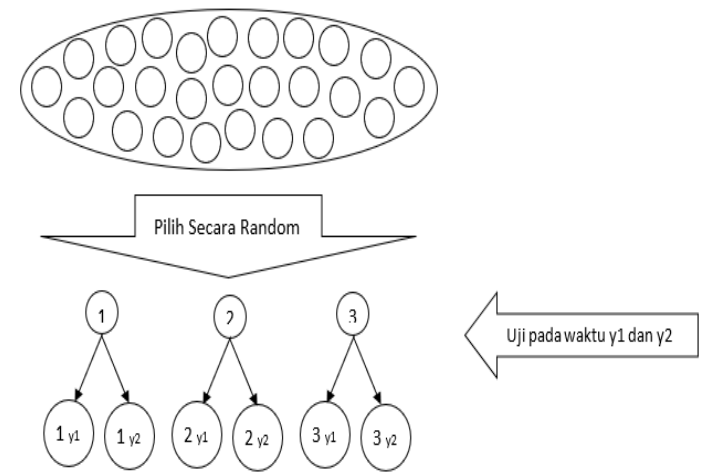

Gambar 2 Skematik Uji Stabilitas

d. Sampel dianggap stabil jika memenuhi persyaratan $\left[\mathrm{x}_{r}-\mathrm{y}_{\mathrm{r}}\right] \leq 0.3 \sigma$, dimana

$$
\begin{aligned}
\mathrm{x}_{\mathrm{r}} & =\text { konsentrasi sampel pada uji } \\
& \text { homogenitas } \\
\mathrm{y}_{\mathrm{r}} & =\text { konsentrasi sampel pada uji stabilitas } \\
\sigma & =\text { standar deviasi untuk asesmen } \\
& \text { profisiensi (SDPA), yang ditetapkan } \\
& \text { dengan perhitungan CV } \text { Horwitz. }^{\text {dengan }}
\end{aligned}
$$

\section{HASIL DAN PEMBAHASAN}

\subsection{Hasil 'Feasibility Study'}

Rangkaian kegiatan feasibility study bermanfaat sebagai rujukan waktu pelaksanaan skema uji profisiensi yang sebenarnya, dengan mempertimbangkan kestabilan analit residu pestisida di dalam kandidat matriks uji profisiensi. Pemilihan waktu pengamatan kestabilan sampel disesuaikan dengan pertimbangan dan asumsi yang didapatkan oleh laboratorium penyiap dengan mempertimbangan referensi yang ada, pengaatan stabilitas residu pestisida pada hari ke-0, ke-3, ke-7, ke-14, ke-21 dan ke-28. Pemilihan waktu pengamatan disesuaikan dengan skema uji profisiensi yang akan diselenggarakan. Pemilihan kondisi penyimpanan sampel dengan pertimbangan sebagai berikut:

a. Kondisi dalam wadah pengiriman yang disimpan di suhu ruang $\left( \pm 25-30{ }^{\circ} \mathrm{C}\right)$, sebagai gambaran saat sampel sedang dikirim ke laboratorium peserta;

b. Kondisi dalam oven suhu $\pm 40^{\circ} \mathrm{C}$, sebagai gambaran suhu terekstrim yang dialami oleh sampel selama pengiriman (dengan pertimbangan adanya ice gel di dalam kemasan pengiriman);

c. Kondisi dalam refrigerator suhu $\pm 4{ }^{\circ} \mathrm{C}$, sebagai gambaran kondisi ideal penyimpanan sampel uji profisiensi. Kondisi dalam freezer suhu $\leq 0{ }^{\circ} \mathrm{C}$, sebagai gambaran kondisi paling ideal penyimpanan sampel uji profisiensi untuk mencegah instabilitas analit residu pestisida target

Beberapa informasi yang sangat membantu laboratorium penyiap sampel uji profisiensi setelah melakukan kegiatan feasibility study:

a. Penambahan pengawet untuk menjaga sampel uji profisiensi dari jamur minimal ataupun kerusakan enzimatis lainnya

b. Rekomendasi perlakuan penyimpanan sampel uji profisiensi setelah diterima oleh laboratorium peserta, sebelum dipreparasi untuk dianalisis

c. Rekomendasi perlakuan sampel tepat saat akan dipreparasi, seperti pengadukan sampel sebelum ditimbang, dan sebagainya

Dari hasil kegiatan feasibility study, laboratorium penyiap sampel uji profisiensi memiliki gambaran trend konsentrasi maupun kestabilan analit residu pestisida target dalam matriks kandidat sampel uji profisiensi selama rentang waktu tertentu dan dalam kondisi tertentu. Hal tersebut bisa menjadi rujukan bagi penyelenggara uji profisiensi saat melakukan evaluasi hasil uji profisiensi peserta nantinya. Tetapi kondisi yang sangat jauh berbeda mungkin akan dihadapi oleh laboratorium penyiap, karena jumlah sampel yang disiapkan untuk kegiatan feasibility study dan skema uji profisiensi yang sebenarnya. Kejadian ini dialami oleh Laboratorium Uji Residu Pestisida, Direktorat Standardisasi dan Pengendalian Mutu, Kementerian Perdagangan saat mempersiapkan sampel residu pestisida pada matriks puree 
stroberi, dimana kelarutan residu pestisida yang dilarutkan dalam solvent organik menjadi berkurang, ketika matriks puree stroberi semakin banyak.

\subsection{Tahapan Penyiapan Sampel Uj Profisiensi Pada Berbagai Matriks}

Sampel yang disiapkan oleh laboratorium penyiap sampel uji profisiensi antaralain:

a. Minimal 10 kemasan sampel untuk uji homogenitas

b. Minimal sejumlah kemasan tertentu sampel untuk dikirimkan ke peserta

c. Minimal 6 kemasan sampel untuk uji stabilitas di awal dan akhir waktu pelaksanaan skema uji profisiensi

d. Minimal 10 kemasan sampel untuk cadangan jika ada inhomogenitas sampel, ataupun kerusakan selama pendistribusian sampel dari laboratorium penyiap ke laboratorium peserta.

e. Beberapa kemasan berdasarkan pertimbangan laboratorium untuk keperluan kontrol sampel ataupun untuk studi stabilitas sampel jangka panjang.

Titik kritis kegiatan penyiapan sampel uji profisiensi yang digarisbawahi oleh laboratorium antara lain:

a. Pemilihan matriks sampel yang akan di uji profisiensi-kan

Ada berbagai cara yang dapat dipilih oleh laboratorium untuk mendapatkan sampel uji profisiensi residu pestisida. Grimalt (2015) melakukannya dengan membuat reference material pada matriks timun dengan cara spiking pada bubuk timun dengan menyemprotkan bubuk pestisida target. Sementara itu di Jepang, mengembangkan reference material pada matriks kedelai dengan cara menyemprotkan pestisida target tiga kali sebelum pemanenan (Yarita ,2013). Sedangkan Laboratorium Uji Residu Pestisida, Direktorat Standardisasi dan Pengendalian Mutu, Kementerian Perdagangan memilih untuk membeli buah stroberi segar di pasaran untuk dijadikan matriks sampel untuk selanjutnya dipreparasi menjadi puree stroberi.

b. Penggilingan dan penyaringan untuk mendapatkan ukuran partikel yang seragam Menurut Bian (2018) matriks yang dipotong tidak beraturan juga berkontribusi pada kehilangan residu pestisida dalam matriks, sehingga laboratorium melakukan penggilingan dan penyaringan untuk menyeragamkan partikel sampel untuk menjaga kestabilan residu pestisida dalam matriks. Selain itu, Fussell (2007), menyarankan untuk melakukan penggilingan dengan kondisi kriogenik. Penggilingan kriogenik mengharuskan sampel dibekukan, biasanya pada $-20 \stackrel{\circ}{\circ}$, sebelum digiling menjadi bubuk serbuk halus dengan penambahan es kering $\left(\mathrm{CO}_{2}\right.$ padat) atau cairan nitrogen. Dengan mengurangi suhu saat penggilingan, potensi reaksi antara residu pestisida yang ada dalam sampel dan bahan kimia / enzim yang dilepaskan ketika sel-sel tanaman dirusak, dapat diperlambat dan hilangnya pestisida dapat diminimalkan. Karena keterbatasan peralatan laboratorium, kondisi ideal seperti yang dianjurkan belum dapat dilaksanakan

c. Penambahan pengawet

Berfungsi untuk mencegah rusaknya sampel karena adanya reaksi enzimatis dari matriks sampel itu sendiri. Menurut Ortiz-Hernandez (2013), di lingkungan alami, pestisida atau produk turunannya dapatdiubah lebih lanjut atau terdegradasi oleh mikroorganisme lain atau akhirnya mengarah ke degradasi total oleh mikroba. Reaksi enzimatik juga dikatakan dapat mendegradasi senyawa pestisida, baik dalam organisme sasaran, melalui intrinsik mekanisme detoksifikasi dan resistensi metabolik yang berkembang, dan di lingkungan yang lebih luas, melalui biodegradasi oleh mikroorganisme tanah dan air. Kenyataan ini menyebabkan penambahan pengawet adalah hal yang mutlak dilakukan, untuk mencegah degradasi pestisida yang ditambahkan, terutama untuk mencegah kerusakan berupa pembusukan matriks sampel itu sendiri, dengan kadar yang tidak mengganggu analisis analit residu pestisida target dalam matriks sampel. Pengawet yang ditambahkan selama ini adalah natrium benzoate. Secara teoritis, natrium benzoate berfungsi untuk menahan bakteri dan jamur dalam kondisi asam dan penggunaannya dalam makanan yang bersifat asam seperti minuman berkarbonasi, jus, selai buah, dll. Secara praktis, natrium benzoate banyak terdapat di pasaran dan gampang didapatkan, sehingga dapat diaplikasikan sebagai pengawet sampel.

d. Penambahan pestisida target ke dalam puree stroberi

Menurut Medina-Pastor (2010), untuk mendapatkan sampel dalam jumlah banyak yang homogen dengan sejumlah besar pestisida, hindari penggunaan pelarut organic yang dapat mempengaruhi recovery normal dan efek matriks, sampel disiapkan pada 
level yang dipilih dengan micro-diffusers yang mengandung pestisida formulasi komersial. Dengan cara ini, pelarut yang digunakan adalah air, seperti perlakuan praktis di lapangan. Dokumen EURL-FV (2013) menjelaskan bahwa ada dua cara untuk melakukan spiking residu pestisida dalam sampel, pertama dengan menggunakan pestisida formulasi komersial dan lainnya dengan menggunalan larutan standar yang dimiliki laboratorium. Alasan untuk menggunakan cara tersebut adalah tergantung dari ketersediaan analit target. Pada skema uji profisiensi terdahulu Laboratorium Uji Residu Pestisida, Direktorat Standardisasi dan Pengendalian Mutu, Kementerian Perdagangan melakukan spiking pada matriks sampel dengan menggunakan larutan standar yang tersedia di laboratorium, tetapi untuk matriks stroberi yang menjadi matriks uji profisiensi tahun 2020, terdapat inhomogenitas ketika spiking sampel dalam jumlah besar semu analit target dilakukan dengan menggunakan larutan standar, sehingga sampel stroberi di spiking dengan menggunakan pestisida formulasi komersial yang dilarutkan dalam air sebagian dan sisanya di spiking dengan larutan standar yang dilarutkan dengan air:pelarut organik (1:1)

e. Pengadukan

Pengadukan ditujukan untuk menyeragamkan komposisi analit target pada setiap bagian matriks sampel, sehingga dapat diperoleh kesimpulan sampel yang homogen.

f. Sampling sebelum pengemasan

Sampling pada beberapa titik container tempat sampel, perhitungan standar deviasi antar konsentrasi sampel yang diambil, dimana sampel dikatakan siap untuk dikemas ke dalam kemasan jika memiliki nilai RSD $\leq$ 5\% (berdasarkan pengalaman laboratorium penyiap sampel uji profisiensi)

g. Pengemasan

Sebelum sampel dikemas, botol pengemasan terlebih dahulu distrerilisasi dengan dengan sinar UV untuk menghilangkan bakteri ataupun jamur yang mungkin ada dalam botol kemasan.

Tahap terakhir dalam skema pengadaan sampel uji profisiensi yang harus diperhatikan juga adalah pengiriman sampel ke peserta. Pengiriman sampel uji profisisensi diusahakan secepatnya, artinya tidak terlalu lama di pengiriman. Penambahan dry ice pada kemasan dilakukan untuk menjaga suhu sampel selama pengiriman untuk menjaga stabilitas analit target.

\subsection{Hasil Perbandingan Homogenitas dan Perbedaan Perlakuan}

Uji homogenitas sampel uji profisiensi dilakukan sesuai dengan prinsip dalam SNI ISO/IEC 17043:2010 dan ISO 13528:2015, dimana sampel dianggap homogen jika memenuhi persyaratan Ss $\leq 0.3 \sigma$, dengan menggunakan beberapa rumus berikut:

$$
\begin{gathered}
S s=\sqrt{S_{x}^{2}-\left(S_{w}^{2} / 2\right)} \\
X t=\left(X_{t 1}+X_{t 2}\right) / 2 \\
W t=\left|X_{t 1}-X_{t 2}\right| \\
X r=\sum X_{r t} / g \\
S x=\sqrt{\sum\left(X_{t}-X_{r}\right)^{2} /(g-1)} \\
S w=\sqrt{\sum W_{t}^{2} /(2 g)} \\
S s=\sqrt{S_{x}^{2}-\left(S_{w}^{2} / 2\right)} \\
C V_{\text {horwitz }}=2^{1-0.5 \log C}
\end{gathered}
$$

$\mathrm{CV}_{\text {Horwitz }}$ digunakan untuk menghitung nilai $\sigma$ (standar deviasi untuk asesmen profisiensi / SDPA)

Dari data yang ditampilkan tabel dibawah ini, pada tabel 2 dan tabel 3 dibuktikan bahwa homogenitas sampel sangat dipengaruhi oleh perlakuan spiking dengan melihat sifat alami matriks sampel uji profisiensi. Dimana spiking stroberi dengan pestisida formulasi komersial akan lebih homogen dibandingkan dengan spiking stroberi dengan larutan standar.

Tabel 2 Evaluasi statistik data homogenisasi stroberi spiking pestisida formulasi dan larutan standar

\begin{tabular}{llcccc}
\hline \multicolumn{1}{c}{ Pestisida } & Pestisida spiking & $\begin{array}{c}\text { Rata-rata } \\
\text { Konsentrasi } \\
(\boldsymbol{\mu g} / \mathbf{K g})\end{array}$ & Ss & 0,3 SDPA & $\begin{array}{c}\text { Ss < 0,3 SDPA } \\
\text { Pass / Fail }\end{array}$ \\
\hline Acephate & Formulasi komersial & 84,47 & 0,72 & 5,88 & Pass \\
Thiacloprid & Larutan standar & 362,49 & 3,39 & 20,27 & Pass \\
Carbofuran & Formulasi komersial & 298,19 & 1,19 & 17,17 & Pass \\
Carbaryl & Larutan standar & 368,93 & 2,48 & 20,58 & Pass \\
Azoxystrobin & Formulasi komersial & 370,63 & 2,62 & 20,66 & Pass
\end{tabular}




\begin{tabular}{|c|c|c|c|c|c|}
\hline Pestisida & Pestisida spiking & $\begin{array}{c}\text { Rata-rata } \\
\text { Konsentrasi } \\
(\mu \mathrm{g} / \mathrm{Kg})\end{array}$ & Ss & 0,3 SDPA & $\begin{array}{c}\text { Ss }<0,3 \text { SDPA } \\
\text { Pass / Fail }\end{array}$ \\
\hline \multirow{3}{*}{$\begin{array}{l}\text { Diazinon } \\
\text { Chlorpyrifos } \\
\text { Methyl }\end{array}$} & Formulasi komersial & \multirow[t]{2}{*}{93,32} & \multirow[t]{2}{*}{0,76} & \multirow[t]{2}{*}{6,40} & \multirow[t]{2}{*}{ Pass } \\
\hline & Larutan standar & & & & \\
\hline & \multirow{3}{*}{$\begin{array}{l}\text { Formulasi komersial } \\
\text { Formulasi komersial }\end{array}$} & 361,48 & 16,95 & 20,22 & Pass \\
\hline Trifloxystrobin & & 171,78 & 3,23 & 10,75 & Pass \\
\hline Methomyl & & 129,06 & 1,89 & 8,43 & Pass \\
\hline
\end{tabular}

Tabel 3 Evaluasi statistik data homogenisasi stroberi spiking larutan standar

\begin{tabular}{llcccc}
\hline \multicolumn{1}{c}{ Pestisida } & Pestisida spiking & $\begin{array}{c}\text { Rata-rata } \\
\text { Konsentrasi } \\
(\boldsymbol{\mu g} / \mathbf{K g})\end{array}$ & Ss & $\mathbf{0 , 3}$ SDPA & $\begin{array}{c}\text { Ss < 0,3 SDPA } \\
\text { Pass / Fail }\end{array}$ \\
\hline Acephate & Larutan standar & 135,60 & $\infty$ & 8,79 & Fail \\
Thiacloprid & Larutan standar & 228,82 & $\infty$ & 13,71 & Fail \\
Carbofuran & Larutan standar & 93,39 & $\infty$ & 6,40 & Fail \\
Carbaryl & Larutan standar & 151,61 & $\infty$ & 9,67 & Fail \\
Azoxystrobin & Larutan standar & 127,79 & $\infty$ & 8,36 & Fail \\
Diazinon & Larutan standar & 39,84 & $\infty$ & 3,11 & Fail \\
Chlorpyrifos & Larutan standar & 147,59 & $\infty$ & 9,45 & Fail \\
Methyl & Larutan standar & 93,06 & $\infty$ & 6,39 & Fail \\
Trifloxystrobin & Larutan standar & 97,54 & $\infty$ & 6,65 & Fail \\
Methomyl & & & & & \\
\hline
\end{tabular}

\subsection{Hasil Uji Stabilitas Sampel Uji Profisiensi}

Uji stabilitas sampel uji profisiensi dilakukan sesuai dengan prinsip dalam SNI ISO/IEC 17043:2010 dan ISO 13528:2015, dimana sampel dianggap stabil jika memenuhi persyaratan $\mathrm{Xr}-\mathrm{Yr} \leq 0.3 \sigma$. Dapat dilihat pada tabel 4, dimana senyawa yang stabil secara teoritis pada waktu stabilita pertama dan kedua hanyalah acephate dan methomyl. Sedangkan tabel 5 merupakan evaluasi data stabilita dibandingkan antar waktu pelaksanaannya, dimana dalam SNI ISO/IEC
17043:2010 disebutkan bahwa stabilitas dilakukan dua kali, di awal rentang waktu pengerjaan sampel oleh peserta uji prosisiensi dan di akhir rentang waktu pengerjaan sampel. Secara umum, data tersebut tidak menunjukkan penurunan konsentrasi pestisida secara signifikan. Hal ini menunjukkan bahwa, selama rentang waktu pengerjaan sampel uji profisiensi, dengan syarat mengikuti petunjuk kondisi penyimpanan yang dianjurkan, dalam rentang waktu yang ditentukan, sampai peserta melakukan analisis, tidak akan mempengaruhi konsentrasi yang diperoleh.

Tabel 4 Evaluasi statistik data stabilita dibandingkan data homogenisasi

\begin{tabular}{lccccc}
\hline \multicolumn{1}{c}{ Pestisida } & $\mathbf{0 , 3 ~ S D P A}$ & $\mathbf{( X r}-\mathbf{Y r}) \mathbf{I}$ & $\begin{array}{c}(\mathbf{X r}-\mathbf{Y r})<\mathbf{0 , 3} \\
\text { SDPA Pass / Fail }\end{array}$ & $\mathbf{( X r}-\mathbf{Y r}) \boldsymbol{I I}$ & $\begin{array}{c}(\mathbf{X r}-\mathbf{Y r})<\mathbf{0 , 3} \\
\text { SDPA Pass / Fail }\end{array}$ \\
\hline Acephate & 5,88 & 5,75 & Pass & 5,78 & Pass \\
Thiacloprid & 20,27 & 35,21 & Fail & 73,90 & Fail \\
Carbofuran & 17,17 & 30,20 & Fail & 22,07 & Fail \\
Carbaryl & 20,58 & 35,69 & Fail & 35,83 & Fail \\
Azoxystrobin & 20,66 & 39,20 & Fail & 31,83 & Fail \\
Diazinon & 6,40 & 15,33 & Fail & 10,90 & Fail \\
Chlorpyrifos Methyl & 20,22 & 56,17 & Fail & 13,12 & Pass \\
Trifloxystrobin & 10,75 & 14,22 & Fail & 28,75 & Fail \\
Methomyl & 8,43 & 1,77 & Pass & 2,95 & Pass \\
\hline
\end{tabular}


Tabel 5 Tabel 5 Uji statistik presisi data dan stabilitas setelah interval waktu

\begin{tabular}{|c|c|c|c|c|c|c|c|c|}
\hline \multirow[b]{2}{*}{ Pestisida } & \multicolumn{8}{|c|}{ Konsentrasi (ng/kg) } \\
\hline & $\begin{array}{c}\text { Hari } 1 \\
\text { (data 1) }\end{array}$ & $\begin{array}{c}\text { Hari } 1 \\
\text { (data 2) }\end{array}$ & $\begin{array}{l}\text { Rerata } \\
1 \text { (M1) }\end{array}$ & $\begin{array}{c}\text { Hari } 2 \\
\text { (data 1) }\end{array}$ & $\begin{array}{c}\text { Hari } 2 \\
\text { (data 2) }\end{array}$ & $\begin{array}{c}\text { Rerata } 2 \\
\text { (M2) }\end{array}$ & $\frac{(M 1-M 2)}{M 1}$ & $\%$ \\
\hline Acephate & 77,71 & 79,74 & 78,72 & 80,14 & 77,23 & 78,69 & 0,0005 & $0 \%$ \\
\hline Thiacloprid & 323,53 & 331,03 & 327,28 & 289,82 & 287,37 & 288,60 & 0,1182 & $12 \%$ \\
\hline Carbofuran & 263,98 & 272,00 & 267,99 & 276,09 & 276,15 & 276,12 & $-0,0303$ & $-3 \%$ \\
\hline Carbaryl & 325,59 & 340,90 & 333,24 & 334,81 & 331,40 & 333,10 & 0,0004 & $0 \%$ \\
\hline Azoxystrobin & 328,63 & 334,25 & 331,44 & 328,63 & 334,25 & 331,44 & 0,0000 & $0 \%$ \\
\hline $\begin{array}{l}\text { Diazinon } \\
\text { Chlorpyrifos }\end{array}$ & 77,21 & 78,78 & 77,99 & 82,83 & 82,01 & 82,42 & $-0,0567$ & $-6 \%$ \\
\hline Methyl & 300,27 & 310,35 & 305,31 & 347,29 & 349,43 & 348,36 & $-0,1410$ & $-14 \%$ \\
\hline Trifloxystrobin & 155,88 & 159,24 & 157,56 & 143,75 & 142,32 & $\begin{array}{c}143,04 \\
132,007\end{array}$ & 0,0922 & $9 \%$ \\
\hline Methomyl & 129,10 & 132,55 & 130,83 & 133,16 & 130,85 & 15 & $-0,0090$ & $-1 \%$ \\
\hline
\end{tabular}

\section{KESIMPULAN}

a. Kegiatan Feasibility Study sangat membantu laboratorium dalam mempersiapkan sampel uji profisiensi yang sebenarnya

b. Terdapat tujuh titik kritis yang harus dilakukan laboratorium penyiap sampel uji profisiensi agar sampel homogen dan stabil sampai di tangan peserta

c. Cara spiking menentukan kehomogenitasan sampel uji profisiensi, dimana pada matriks stroberi, spiking dengan menggunakan pestisida formulasi lebih homogen dibandingkan dengan larutan standar laboratorium

d. Jika mengacu pada ISO 13528:2015, dimana sampel dianggap stabil jika memenuhi persyaratan $\mathrm{Xr}-\mathrm{Yr} \leq 0.3 \sigma$, pestisida yang stabil hanya Acephate dan Methomyl

e. Jika dibandingkan antar waktu pengujian stabilitas selama rentang waktu pengerjaan sampel uji profisiensi, tidak terdapat penurunan konsentrasi pestisida secara signifikan

\section{UCAPAN TERIMAKASIH}

Puji dan syukur penulis panjatkan ke hadirat Tuhan Yang Maha Kuasa, atas berkat dariNya penulis bisa menuangkan sebagian kecil hasil pemikirannya dalam makalah ini. Tak lupa penulis mengucapkan terimakasih kepada pimpinan Balai Pengujian Mutu Barang beserta stafnya yang memberikan kesempatan seluas-luasnya untuk dapat mengembangkan diri melalui makalah ini. Terimakasih pula kepada keluarga kecilku dan rekan-rekan laboratorium residu pestisida, Balai Pengujian Mutu Barang Direktorat Standardisasi dan Pengendalian Mutu, Kementerian Perdagangan, yang banyak memberikan dukungan baik moril maupun materiil kepada penulis.

\section{DAFTAR PUSTAKA}

SNI ISO/IEC 17043:2010. Penilaian kesesuaian - Persyaratan umum uji profisiensi

ISO/IEC Guide 43:1997(E). Proficiency testing by interlaboratory comparisons

ISO 13528:2015. Statistical methods for use in proficiency testing by interlaboratory comparisons

ISO Guide 34:2009(E). General requirements for the competence of reference material producers

ISO Guide 35:2006. Reference materials General and statistical principles for certification of reference material

SNI ISO/IEC 17025:2017. Standar persyaratan umum kompetensi laboratorium penguji dan kalibrasi

SNI 7313:2008. Batas maksimum residu pestisida pada hasil pertanian

EN 15662:2008 standard. (2008).Foods of Plant Origin. Determination of Pesticide Residues Using GC-MS and/or LCMS/MS Following Acetonitrile Extraction/Partitioning and Clean-up by Dispersive SPE. QuEChERS-Method

SANTE/11813/2017. Guidance document on analytical quality control and method validation procedures for pesticides residues analysis in food and feed

Regulation (EC) No 396/2005 of the European Parliament and of The Council of 23 
February 2005 on maximum residue levels of pesticides in or on food and feed of plant and animal origin and amending Council Directive 91/414/EEC

Palupi, M. F. (2014). Uji homogenitas dan stabilitas sampel uji profisiensi sediaan obat hewan siprofloksasin serbuk. [Homogeneity and stability test of sample proficiency test of powdered ciprofloxacin veterinary drug preparations] Buletin Pengujian Mutu Obat Hewan No. 22 tahun 2014

Aidah, S. (2008). Uji homogenitas sampel $\cup_{2}$ dan $\mathrm{U}_{3} \mathrm{O}_{8}$ untuk uji profisiensi. [Homogeneity test of $\mathrm{UO}_{2}$ and $\mathrm{U}_{3} \mathrm{O}_{8}$ samples for proficiency testing] Prosiding Seminar Pengelolaan Perangkat Nuklir tahun 2008. PTBNBATAN, Serpong 29 Juli 2008

European Commission. Information on pesticide EU MRLs [internet]. Retrieved September 5, 2020 from http://ec.europa.eu/food/plant/protection/ pesticides/index_en.htm

53/PERMENTAN/KR.040/12/2018. Peraturan Menteri Pertanian Republik Indonesia tentang keamanan dan mutu pangan segar asal tumbuhan

Grimalt, S. (2015). Development of a new cucumber reference material for pesticide residue analysis: feasibility study for material processing, homogeneity and stability assessment. Anal Bioanal Chem 407, 3083-3091

Yarita, T. (2013). Development of soybean certified reference material for pesticide residue analysis. Talanta Journal. https://doi.org/10.1016/j.talanta.2013.11. 011

Bian, L. (2018). Storage stability of three organophosphorus pesticides on cucumber samples for analysis. Food Chem. Jun 1, 2018; 250, 230-235

Fussell, R. J. (2007). Assessment of the Stability of Pesticides During the Cryogenic Processing of Fruits and Vegetables. Food Additives and Contaminants Journal. 2007, 24 (11), pp.1247-1256.

Ortiz-Hernandez, Ma, L. (2013). Pesticide Biodegradation: Mechanisms, Genetics and Strategies to Enhance the Process. Biodegradation - Life of Science, Chapter 10 pp. 251-286.

Medina-Pastor, P. (2010). European Commission proficiency tests for pesticide residues in fruits and vegetables. Trends in Analytical Chemistry, Vol. 29, No.1.

EURL for Pesticide Residues in Fruits and Vegetables (EURL-FV). 2013 Activity Program 